\title{
A simple and efficient method of generating HCMV pp65-specific $T$ cells using overlapping peptides
}

\author{
S.-U. HWANG ${ }^{\# \#, ~ J .-H . ~ L E E ~}{ }^{1 \#, ~ S .-Y . ~ C H O I ~}{ }^{2 \#}$, Y.-T. LEE ${ }^{1}$, S.-Y. PARK ${ }^{2}$, H. S. LEE ${ }^{1}$, J. W. JAE ${ }^{1}$, \\ N.-C. JUNG ${ }^{1}$, Y. WANG ${ }^{3}$, D.-S. LIM ${ }^{2 *}$
}

\begin{abstract}
${ }^{1}$ Pharosvaccine Inc., Dunchon-daero, Jungwon-gu, Seongnam-si, Gyeonggi-do 462-807, Republic of Korea; ${ }^{2}$ Department of Biotechnology, CHA University, 335 Pangyo-ro, Bundang-gu, Seongnam-si, Gyeonggi-do 13488, Republic of Korea; ${ }^{3}$ Immunotech Applied Science Ltd., Beijing 100176, P. R. China
\end{abstract}

Received September 10, 2019; revised February 24, 2020; accepted November 3, 2020

\begin{abstract}
Summary. - The methods for expansion of human cytomegalovirus (HCMV)-specific T lymphocytes are limited due to the complex culture process, long culture duration, and human leukocyte antigen (HLA) restriction. Here, we report that in vitro stimulation with $\mathrm{pp} 65 \mathrm{kDa}$ phosphoprotein (pp65)-derived overlapping synthetic peptides rapidly generates large numbers of HCMV-specific cytotoxic T lymphocytes from peripheral blood mononuclear cells (PBMCs) regardless of HLA type. Treatment of PBMCs from healthy volunteers expressing HLA-A* $02: 01$ or HLA-A*24:02 with 138 pp65 overlapping peptides (OLP) resulted in an expansion of HCMV pp65 NLVPMVATV (NLV) pentamer-specific CD8 ${ }^{+} \mathrm{T}$ lymphocytes that expressed interferon(IFN)- $\gamma$, but the pp65 NLV peptide did not generate HCMV-specific CD8 ${ }^{+}$T lymphocytes in PBMCs obtained from an HLA-A*24:02 donor due to HLA restriction. The OLP-induced T lymphocytes specific for HCMV derived from PBMCs of HLA-A*02:01- and HLA-A*24:02-expressing donors showed effective cytolytic responses against target cells loaded with OLP or the NLV epitope, but pp65 NLV peptide-induced T lymphocytes did not. Phenotypic analyses demonstrated that OLP increased the frequency of CD3 ${ }^{+}$CD8 ${ }^{+}$ cells, but not $\mathrm{CD}^{+} \mathrm{CD} 4^{+}, \mathrm{CD} 14^{+}$, or $\mathrm{CD} 56^{+}$cells, in donor PBMCs. Thus, this study provides evidence that in vitro stimulation with OLP efficiently generates sufficient numbers of HCMV pp65-specific cytotoxic $\mathrm{T}$ lymphocytes for adoptive cell therapy.
\end{abstract}

Keywords: human cytomegalovirus; cytotoxic T lymphocyte; overlapping peptides; pp65; cytotoxicity

\section{Introduction}

Allogeneic hematopoietic stem cell transplantation (HSCT) is an effective treatment for various diseases, in cluding malignant lymphoma, multiple myeloma, refrac-

"Corresponding author. E-mail: dslim@cha.ac.kr; phone: +8231-881-7122. "These authors contributed equally to this study. Abbreviations: $\mathrm{APCs}=$ antigen-presenting cells; $\mathrm{BLCLs}=\mathrm{B}$ lymphoblastic cell lines; CTLs = cytotoxic $\mathrm{T}$ lymphocytes; $\mathrm{EBV}=$ Epstein-Barr virus; GvHD = graft versus host disease; HCMV = human cytomegalovirus; $\mathrm{HSCT}$ = hematopoietic stem cell transplantation; OLP = overlapping peptides; PBMCs = peripheral blood mononuclear cells tory autoimmune disease, some solid tumors, and leukemia. However, due to immune suppression, transplant patients are at a high risk of death due to infectious complications; more than $30 \%$ die from opportunistic infections with viruses such as human cytomegalovirus (HCMV), adenovirus, Epstein-Barr virus (EBV), and the varicella zoster virus (Koc et al., 2000; Sahin et al., 2016; Chan and Logan, 2017). Of these, HCMV is one of the most common infectious complications of transplantation (Aandahl et al., 2004; Varani et al., 2009). This partly reflects the fact that it is a ubiquitous pathogen that chronically infects hosts for life. Although this chronic infection is normally controlled by the immune system, it is associated with dysfunctional immune responses in older individuals, including weakened responses to new pathogens and 
vaccines (Aiello and Simanek, 2012). Moreover, despite substantial medical advances, it remains a major cause of morbidity as well as mortality in patients, who receive T cell-depleted grafts, HSCT, or solid organ transplants (SOT), or who undergo prolonged immunosuppression. Indeed, it frequently precedes graft versus host disease (GvHD); these effects are due to both direct adverse effects caused by viral invasion of the organ system and indirect effects on the immune system, which increase the risk of other infections and promote acute graft rejection (GallezHawkins et al., 2009; Hasanzamani et al., 2016).

To resolve this problem, transplant patients can be treated with antiviral agents that reduce virus load; these agents include ganciclovir, foscarnet, cidofovir, and acyclovir (Gerna et al., 1994; Cihlar et al., 1998; Biron, 2006). However, prolonged antiviral treatment may delay the recovery of virus-specific immune responses and can promote the emergence of resistance. Moreover, antiviral drug treatment often cannot be sustained because of complicating myelosuppression or nephrotoxicity (Chou, 2001).

Several additional strategies have been devised to treat HCMV-related diseases. One of these is the adoptive transfer of HCMV-specific T cells. This approach is based on animal studies with murine CMV that showed that CD8 ${ }^{+}$CMV-specific cytotoxic T lymphocytes (CTLs) play a key role in controlling CMV replication (Reddehase et al., 1987). Moreover, Potena et al. showed that in the absence of preventive ganciclovir therapy, only $50 \%$ of patients who underwent allogeneic HSCT had detectable CTL responses 3 months after transplantation (Potena et al., 2016). In addition, a randomized clinical trial showed that the frequency of CMV-specific CTLs correlated positively with protection from HCMV infectious complications, namely GvHD (Li et al., 1994). These findings suggest that adoptive immunotherapy, where the patient is transfused with HCMV-specific CTLs, may prevent HCMV infection or reactivation.

At present, adoptive immunotherapy against HCMV is hampered by a number of immunological and practical issues. First, the optimal HCMV target protein(s)/peptide(s) remain unclear. Sylwester et al. showed that healthy HCMV-infected adults (but not seronegative adults) generally exhibited strong in vitro $\mathrm{CD} 8{ }^{+} \mathrm{T}$ cell responses to a subset of 13,687 peptides that overlapped HCMV open reading frames; on average, $10.2 \%$ of the total memory $\mathrm{CD}^{+} \mathrm{T}$ cell repertoire of these subjects recognized a median of eight (range, 1-30) HCMV peptides. Indeed, up to $30 \%$ of the memory $\mathrm{CD}^{+} \mathrm{T}$ cells of some subjects responded to HCMV peptides (Sylwester et al., 2005). However, there was extensive variability among individuals in terms of the magnitude of their anti-HCMV T cell response. The reasons for this variability are not fully understood but may include the dose and timing of the HCMV infection, major histocompatibility class restriction, and competition between high- and low-affinity $\mathrm{T}$ cell clones during in vivo expansion (the high-avidity cells are preferentially selected early after infection and retain their dominance throughout latency). The second issue hampering adoptive immunotherapy against HCMV is that it takes weeks to months to prepare sufficient numbers of clinical-grade CTLs in vitro for transfer. First, the antigen-presenting cells (APCs) must be prepared; these are either dendritic cells (Peggs et al., 2001) or EBV-transformed B lymphoblastic cell lines (BLCLs) (Ramadan, 2008). Thereafter, the CTLs must be stimulated with the peptide-loaded APCs (Vannucchi et al., 2001; Leen et al., 2006). Lilleri et al. showed recently that within 3 months of transplantation, the majority of seropositive HSCT recipients (62\%) exhibited an increase in HCMV DNA in the blood, prompting pre-emptive treatment (Lilleri et al., 2012). The costs associated with CTL production and the complexity of production also hamper adoptive immunotherapy in HSCT recipients (Leen et al., 2010).

pp65 is the most abundant tegument protein and the major tegument protein responsible for modulating/ evading the host cell immune response during HCMV infections (McLaughlin-Taylor et al., 1994; Chevillotte et al., 2009). This viral structural protein has been identified as a target antigen for HCMV-specific class I MHC restricted CTL derived from the peripheral blood of most asymptomatic HCMV-seropositive individuals. Also, pp65 mainly targets both humoral and cellular immunity and serves as the dominant targeting antigen of cytotoxic T lymphocytes. (McLaughlin-Taylor et al., 1994; Tomtishen, 2012). The overlapping peptide, which was mainly used to search for immunogenic epitopes on immune cells, was used as an antigen. Unlike the epitope peptide, the overlapping peptide mixture is not limited to HLA type, and it is known that it can stimulate CD8+ $\mathrm{T}$ cells more effectively than when using viral lysates or proteins recognized as exogeneous antigens (Holden $\mathrm{T}$ et al.,2001). The aim of this study was to determine whether HCMV-specific CTLs can be effectively expanded from peripheral blood mononuclear cells (PBMCs) using a mixture of peptides that overlap the HCMV pp65 protein. Here, we show that this approach is feasible and may be useful for adoptive immunotherapy of HCMV-infected HSCT recipients.

\section{Materials and Methods}

Donors. Nine healthy volunteers (eight expressing HLA$A^{*} 02: 01$ and one expressing HLA-A*24:02) were enrolled in this study. All procedures involving the human participants 
Table 1. Overlapping peptide pool of 138 peptides derived from a peptide scan (15 mers with 11 amino acid overlap) through HCMV pp65 (Swiss Prot ID: P06725)

\begin{tabular}{|c|c|c|c|c|c|}
\hline No. & Amino acid sequence & No. & Amino acid sequence & No. & Amino acid sequence \\
\hline 1 & MESRGRRCPEMISVL & 47 & AFVFPTKDVALRHVV & 93 & FTSQYRIQGKLEYRH \\
\hline 2 & GRRCPEMISVLGPIS & 48 & PTKDVALRHVVCAHE & 94 & YRIQGKLEYRHTWDR \\
\hline 3 & PEMISVLGPISGHVL & 49 & VALRHVVCAHELVCS & 95 & GKLEYRHTWDRHDEG \\
\hline 4 & SVLGPISGHVLKAVF & 50 & HVVCAHELVCSMENT & 96 & YRHTWDRHDEGAAQG \\
\hline 5 & PISGHVLKAVFSRGD & 51 & AHELVCSMENTRATK & 97 & WDRHDEGAAQGDDDV \\
\hline 6 & HVLKAVFSRGDTPVL & 52 & VCSMENTRATKMQVI & 98 & DEGAAQGDDDVWTSG \\
\hline 7 & AVFSRGDTPVLPHET & 53 & ENTRATKMQVIGDQY & 99 & AQGDDDVWTSGSDSD \\
\hline 8 & RGDTPVLPHETRLLQ & 54 & ATKMQVIGDQYVKVY & 100 & DDVWTSGSDSDEELV \\
\hline 9 & PVLPHETRLLQTGIH & 55 & QVIGDQYVKVYLESF & 101 & TSGSDSDEELVTTER \\
\hline 10 & HETRLLQTGIHVRVS & 56 & DQYVKVYLESFCEDV & 102 & DSDEELVTTERKTPR \\
\hline 11 & LLQTGIHVRVSQPSL & 57 & KVYLESFCEDVPSGK & 103 & ELVTTERKTPRVTGG \\
\hline 12 & GIHVRVSQPSLILVS & 58 & ESFCEDVPSGKLFMH & 104 & TERKTPRVTGGGAMA \\
\hline 13 & RVSQPSLILVSQYTP & 59 & EDVPSGKLFMHVTLG & 105 & TPRVTGGGAMAGAST \\
\hline 14 & PSLILVSQYTPDSTP & 60 & SGKLFMHVTLGSDVE & 106 & TGGGAMAGASTSAGR \\
\hline 15 & LVSQYTPDSTPCHRG & 61 & FMHVTLGSDVEEDLT & 107 & AMAGASTSAGRKRKS \\
\hline 16 & YTPDSTPCHRGDNQL & 62 & TLGSDVEEDLTMTRN & 108 & ASTSAGRKRKSASSA \\
\hline 17 & STPCHRGDNQLQVQH & 63 & DVEEDLTMTRNPQPF & 109 & AGRKRKSASSATACT \\
\hline 18 & HRGDNQLQVQHTYFT & 64 & DLTMTRNPQPFMRPH & 110 & RKSASSATACTSGVM \\
\hline 19 & NQLQVQHTYFTGSEV & 65 & TRNPQPFMRPHERNG & 111 & SSATACTSGVMTRGR \\
\hline 20 & VQHTYFTGSEVENVS & 66 & QPFMRPHERNGFTVL & 112 & ACTSGVMTRGRLKAE \\
\hline 21 & YFTGSEVENVSVNVH & 67 & RPHERNGFTVLCPKN & 113 & GVMTRGRLKAESTVA \\
\hline 22 & SEVENVSVNVHNPTG & 68 & RNGFTVLCPKNMIIK & 114 & RGRLKAESTVAPEED \\
\hline 23 & NVSVNVHNPTGRSIC & 69 & TVLCPKNMIIKPGKI & 115 & KAESTVAPEEDTDED \\
\hline 24 & NVHNPTGRSICPSQE & 70 & PKNMIIKPGKISHIM & 116 & TVAPEEDTDEDSDNE \\
\hline 25 & PTGRSICPSQEPMSI & 71 & IIKPGKISHIMLDVA & 117 & EEDTDEDSDNEIHNP \\
\hline 26 & SICPSQEPMSIYVYA & 72 & GKISHIMLDVAFTSH & 118 & DEDSDNEIHNPAVFT \\
\hline 27 & SQEPMSIYVYALPLK & 73 & HIMLDVAFTSHEHFG & 119 & DNEIHNPAVFTWPPW \\
\hline 28 & MSIYVYALPLKMLNI & 74 & DVAFTSHEHFGLLCP & 120 & HNPAVFTWPPWQAGI \\
\hline 29 & VYALPLKMLNIPSIN & 75 & TSHEHFGLLCPKSIP & 121 & VFTWPPWQAGILARN \\
\hline 30 & PLKMLNIPSINVHHY & 76 & HFGLLCPKSIPGLSI & 122 & PPWQAGILARNLVPM \\
\hline 31 & LNIPSINVHHYPSAA & 77 & LCPKSIPGLSISGNL & 123 & AGILARNLVPMVATV \\
\hline 32 & SINVHHYPSAAERKH & 78 & SIPGLSISGNLLMNG & 124 & ARNLVPMVATVQGQN \\
\hline 33 & HHYPSAAERKHRHLP & 79 & LSISGNLLMNGQQIF & 125 & VPMVATVQGQNLKYQ \\
\hline 34 & SAAERKHRHLPVADA & 80 & GNLLMNGQQIFLEVQ & 126 & ATVQGQNLKYQEFFW \\
\hline 35 & RKHRHLPVADAVIHA & 81 & MNGQQIFLEVQAIRE & 127 & GQNLKYQEFFWDAND \\
\hline 36 & HLPVADAVIHASGKQ & 82 & QIFLEVQAIRETVEL & 128 & KYQEFFWDANDIYRI \\
\hline 37 & ADAVIHASGKQMWQA & 83 & EVQAIRETVELRQYD & 129 & FFWDANDIYRIFAEL \\
\hline 38 & IHASGKQMWQARLTV & 84 & IRETVELRQYDPVAA & 130 & ANDIYRIFAELEGVW \\
\hline 39 & GKQMWQARLTVSGLA & 85 & VELRQYDPVAALFFF & 131 & YRIFAELEGVWQPAA \\
\hline 40 & WQARLTVSGLAWTRQ & 86 & QYDPVAALFFFDIDL & 132 & AELEGVWQPAAQPKR \\
\hline 41 & LTVSGLAWTRQQNQW & 87 & VAALFFFDIDLLLQR & 133 & GVWQPAAQPKRRRHR \\
\hline 42 & GLAWTRQQNQWKEPD & 88 & FFFDIDLLLQRGPQY & 134 & PAAQPKRRRHRQDAL \\
\hline 43 & TRQQNQWKEPDVYYT & 89 & IDLLLQRGPQYSEHP & 135 & PKRRRHRQDALPGPC \\
\hline 44 & NQWKEPDVYYTSAFV & 90 & LQRGPQYSEHPTFTS & 136 & RHRQDALPGPCIAST \\
\hline 45 & EPDVYYTSAFVFPTK & 91 & PQYSEHPTFTSQYRI & 137 & DALPGPCIASTPKKH \\
\hline 46 & YYTSAFVFPTKDVAL & 92 & EHPTFTSQYRIQGKL & 138 & GPCIASTPKKHRG \\
\hline
\end{tabular}

in this study were conducted in accordance with the ethical standards of institutional and national research committees and with the Helsinki Declaration and its later amendments. The experiments were approved by JW CreaGene (certificate No. JWC-IRB-2014-01). Written, informed consent was obtained from all volunteers in advance.

Generation of the NLV peptide and overlapping peptides. The 9-mer peptide that spans the HLA-A*02:01 binding epitope of the HCMV pp65 protein (495-504; NLVPMVATV) was synthesized by JPT Peptide Technologies. The same company also generated 138 15-mer peptides that spanned the entire HCMV pp65 protein (Swiss Prot ID: P06725) and overlapped their neighbors by 11 amino acids. The NLV epitope is contained in full within peptides 123 and 124 (Table 1). Each peptide was diluted with DMSO to a concentration of $100 \mathrm{mg} / \mathrm{ml}$. The reconstituted overlapping peptides (OLP) were then combined into a mixture, in which each peptide was present at a final concentration of $1 \mathrm{mg} / \mathrm{ml}$. The NLV peptide was also diluted to a concentration of $1 \mathrm{mg} / \mathrm{ml}$. The diluent in all cases was RPMI 1640 (Lonza, Verviers, Belgium).

Expansion of HCMV-specific T cells. In total 15-20 ml peripheral blood was collected from healthy volunteers. The PBMCs 
were isolated by Ficoll-Paque density gradient centrifugation (GE Healthcare Life Sciences, NJ, USA), and $2 \times 10^{6}$ PBMCs were suspended in $1 \mathrm{ml}$ RPMI 1640 supplemented with $3 \%$ autologous plasma, $2 \mathrm{mM}$ Glutamax, and $50 \mu \mathrm{M} 2$-mercaptoethanol (Thermo Fisher Scientific, Waltham, MA, USA). The cells were then placed in $14 \mathrm{ml}$ polypropylene round-bottom tubes and pulsed with $1 \mu \mathrm{g} / \mathrm{ml}$ of the NLV epitope or $100 \mathrm{ng} / \mathrm{ml}$ of the OLP mixture. The cells were incubated at $37^{\circ} \mathrm{C}$ in a $5 \% \mathrm{CO}_{2}$ humidified incubator for 2 days, after which $1 \mathrm{ml}$ fresh culture medium containing $100 \mathrm{IU} / \mathrm{ml}$ recombinant human (rh)IL-2 was added. On day 6, the culture medium was replaced with fresh medium containing the same concentration of rhIL-2. This was repeated every 2-3 days for a total of 14 days of incubation.

Flow cytometry analysis. To identify HCMV-specific CTLs in PBMCs or cell lines, the PBMCs/cell lines were stained with APC-anti-CD8 (clone RPA-T8; BD Pharmingen, San Jose, CA, USA; diluted 1:200) and PE-HCMV-pp65 495-504 pentamer (ProImmune, UK; diluted 1:200). For surface phenotype analyses, the cells were stained with anti-CD3 (clone: UCHT1), antiCD14 (clone: M5E2), anti-CD19 (clone: HIB19), anti-CD56 (clone: B159), and anti-CD69 (clone: FN50) (all from BD Pharmingen; all diluted 1:200) on ice for $20 \mathrm{~min}$, and then washed with PBS containing $1 \%$ bovine serum albumin (BSA). To determine the percentage of cells expressing interferon gamma (IFN- $\gamma$ ), the cells were washed and stained with APC-anti-CD8, and then fixed and permeabilized using an intracellular staining kit (BD Biosciences), and stained with FITC-anti-IFN- $\gamma$ (clone: 4S.B3; BD Pharmingen; diluted 1:200). Flow cytometry was performed on a FACSCalibur instrument (BD Biosciences). All data were analyzed with FlowJo software (TreeStar Inc., San Carlos, CA, USA).

Cytotoxicity assay. To assess the cytotoxicity, the HCMVspecific CTLs were cultured with target cells (autologous BLCLs or HLA-matched T2 cells). To generate autologous BLCLs, donor PBMCs were cultured for 3 weeks in a $37^{\circ} \mathrm{C} \mathrm{CO}_{2}$ incubator with $1 \mu \mathrm{g} / \mathrm{ml}$ cyclosporine A and EBV-containing supernatant harvested from a marmoset cell line (B98-8). The autologous BLCLs and the HLA-A*02:01-expressing T2 cells were then pulsed overnight at $37^{\circ} \mathrm{C}$ in a $\mathrm{CO}_{2}$ incubator with or without $10 \mu \mathrm{g} / \mathrm{ml}$ of the NLV peptide or OLP. The cells were plated in 96-well roundbottom plates at effector:target (E:T) ratios of 5:1, 10:1, and 20:1. After another 4 hours of incubation, the cells were pelleted by centrifugation, and the lactate dehydrogenase (LDH) activity in cell-free supernatants was measured by using the CytoTox96 non-radioactive assay kit (Promega, WI, USA) according to the manufacturer's protocol.

Statistical analysis. The data are expressed as the mean \pm SEM. Statistical comparisons were performed using Student's $t$-tests or one-way analysis of variants (ANOVA) followed by Newman-Keul's tests. Differences were considered statistically significant at $P<0.05$. All statistical analyses were performed on GraphPad Prism V7.0 software (GraphPad Software, San Diego, CA, USA).

\section{Results}

\section{Generation of HCMV pp65-specific CTLs}

The PBMCs of eight volunteers expressing HLA*02:01 were first assessed for the presence of $\mathrm{CD} 8^{+} \mathrm{T}$ cells that were specific for the HLA*02:01-presented NLV epitope of HCMV pp65 by staining with anti-CD8 and the HCMVpp65 495-504 pentamer. Three donors (\#2, \#7, and \#8) showed NLV epitope-specific CTLs in the PBMCs, ranging in frequency from $0.2 \%$ to $0.37 \%$ (Fig. 1a), but NLV-specific $\mathrm{T}$ cells were detected at a lower frequency $(<0.2 \%)$ in the other donors. Based on the pentamer staining data, we selected those three donors (\#2, \#7 and \#8) to use for the generation of NLV-specific $\mathrm{T}$ cells by stimulation with OLP. The HCMV-specific CTLs that were generated from these three donors with OLP that spanned the entirety of pp65 protein are referred to as OLP-T. The method that was employed is depicted in Fig. 1b. In five independent experiments using PBMCs from the same three donors, after 14 days of stimulation with OLP in the presence of IL-2, the number of $\mathrm{NLV}$ pentamer ${ }^{+} \mathrm{CD} 8{ }^{+} \mathrm{T}$ cells increased from $0.2-0.37 \%$ to $30 \%$ on average (Fig. 1c,d). Thus, by the end of the 14 day culture period, the population of NLV pentamer ${ }^{+} \mathrm{CD}^{+} \mathrm{T}$ cells had expanded by 78.4-fold (Fig. 1d). These results show that the method depicted in Fig. $1 \mathrm{~b}$ reliably and effectively expands HCMV-specific CTLs.

\section{Cytotoxicity of the HCMV pp65-specific CTLs}

In an independent set of experiments, HCMV pp65specific CTLs from the same three donors (\#2, \#7, and \#8) were generated using the NLV peptide and are referred to as NLV-T. The NLV epitope expanded NLV-specific CTLs as effectively as the OLP (Fig. 2a). Moreover, the NLV epitope and the OLP generated similar frequencies to IFN- $\gamma^{+} \mathrm{CD}^{+}$ $\mathrm{T}$ cells on day 14 of culture (Fig. $2 \mathrm{~b}$ ). Thus, stimulation with OLP generated HCMV pp65 epitope-specific and IFN- $\gamma$-expressing CD8 ${ }^{+} \mathrm{T}$ cells as efficiently as the epitope peptide itself.

The HCMV-specific cytotoxicity of all generated T cells was assessed using T2 cells or autologous BLCLs that had been pulsed with OLP or the NLV peptide as the targets. The three donors differed in terms of the cytotoxicity of their generated CTLs, irrespective of the peptide(s) used to generate them; for example, Donor 8-derived OLP-T killed NLV-loaded T2 cells (NLV-T2) more efficiently than Donor 2- and 7-derived OLP-T. Notably, OLP-T killed NLVT2 almost as well as NLV-T (Fig. 2c). Moreover, OLP-T killed OLP-loaded autologous BLCLs (OLP-BLCL) as well as NLV-loaded autologous BLCLs (NLV-BLCL) (Fig. 2d). In addition, we generated OLP-T from the HLA-A*24:02-expressing donor (Donor 9). Donor 9-derived OLP-T exerted 
(a)

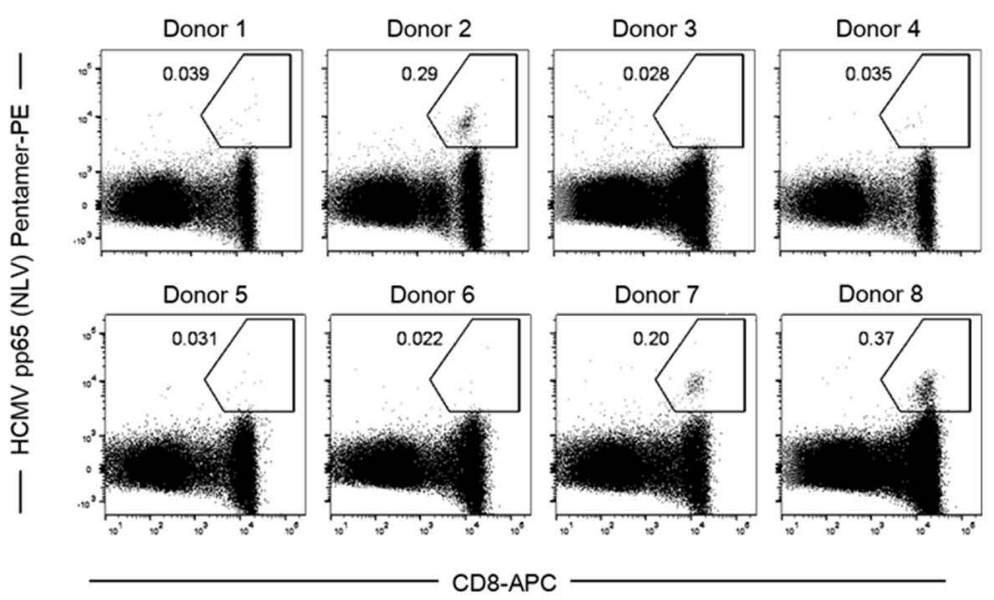

(b)

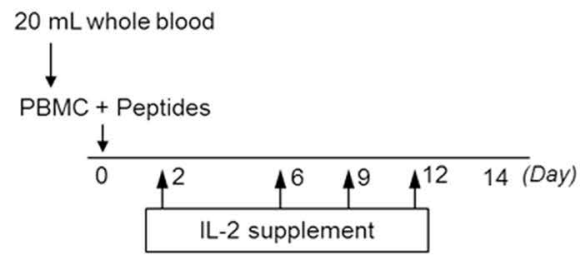

(c)

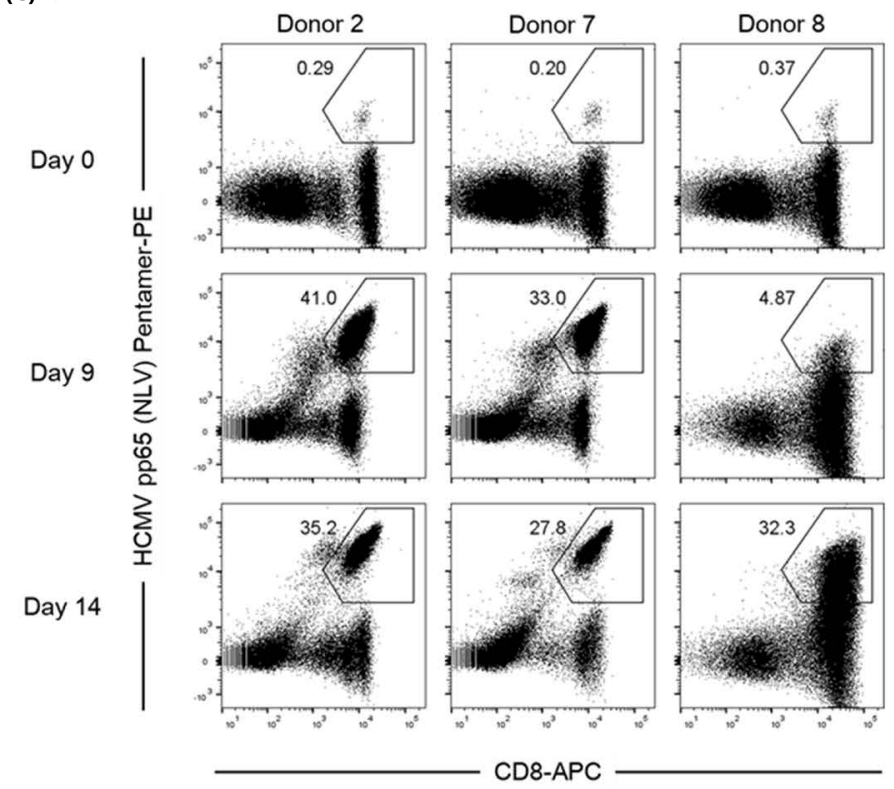

(d)

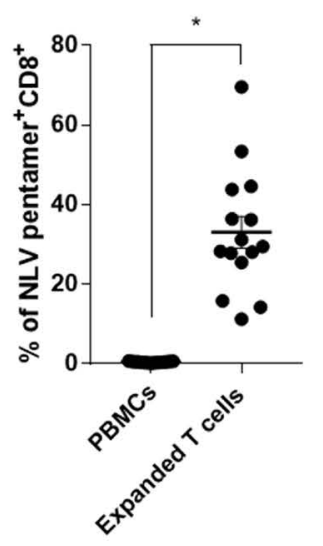

Fig. 1

Generation of HCMV pp65-specific $\mathrm{CD}^{+} \mathrm{T}$ cells using overlapping peptides

(a) The frequency of HCMV pp65 NLV-specific CD8 ${ }^{+}$T cells in peripheral blood mononuclear cells (PBMCs) of healthy volunteers. Blood samples were obtained from eight healthy HLA-A*02:01-expressing donors. The cells were stained with anti-CD8 and an HCMV pp65 NLV epitope pentamer, and analyzed by flow cytometry. (b) Schematic depiction of the method used to generate HCMV pp65-specific CD8 ${ }^{+} \mathrm{T}$ cells. (c) Change over time in the frequency of NLV-specific CD8 ${ }^{+} \mathrm{T}$ cells in PBMCs cultured with OLP as described in Fig. 1b. PBMCs from the subjects with high frequencies (>0.2\%) of NLV-specific CD8 ${ }^{+} \mathrm{T}$ cells (Donors 2, 7, and 8 ) were stimulated with OLP, and CD8/pentamer double-positive cells were counted at days 0,9 , and 14 by flow cytometry. The data shown are representative of five independent experiments with each of the three donors. (d) Frequencies of NLV-specific CD8 ${ }^{+} \mathrm{T}$ cells on days 0 and 14, as determined by flow cytometry. The data from five independent experiments with each of the three donors are shown. ${ }^{*} P<0.05$. 
(a)
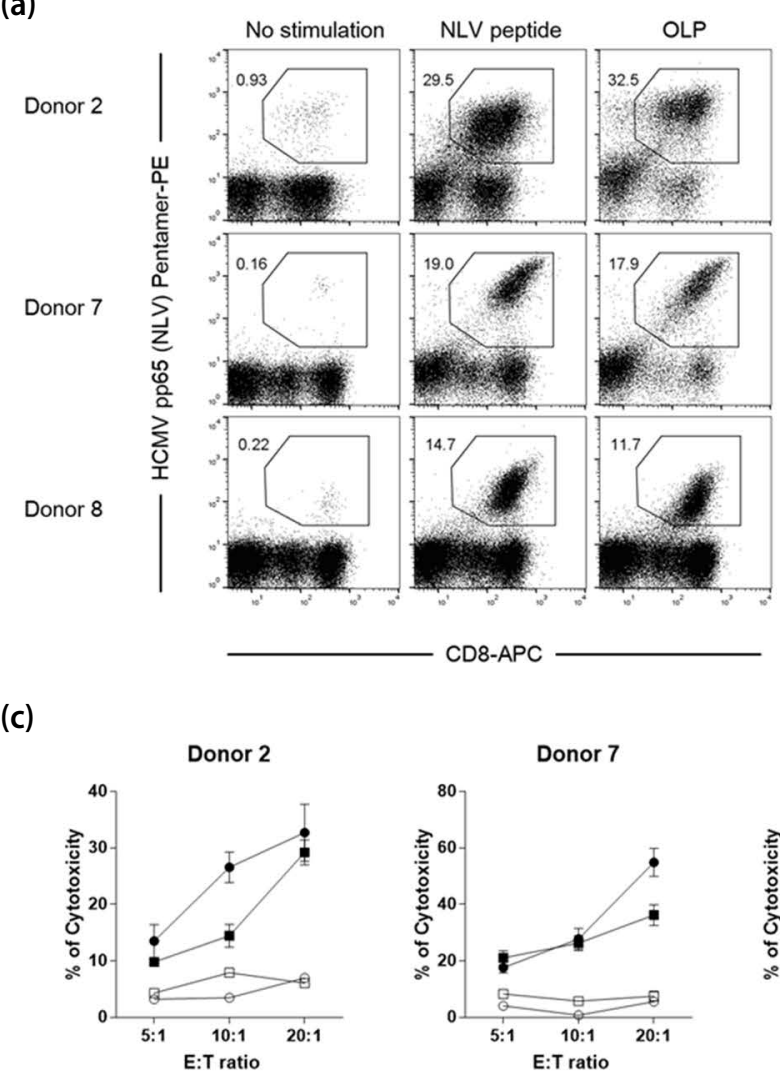

CD8-APC

(c)

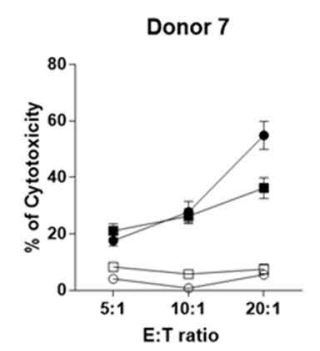

(b)

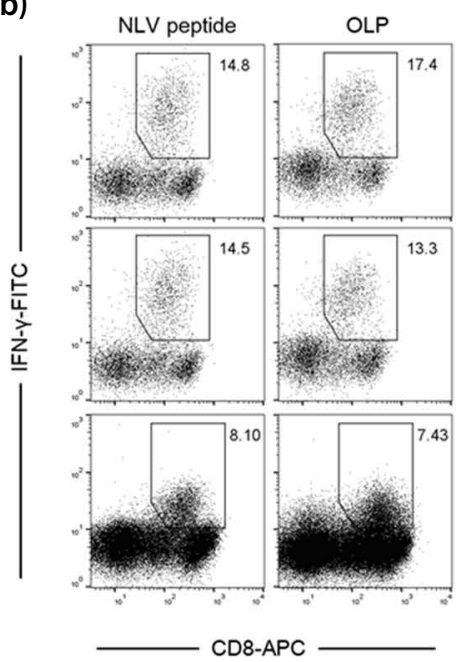

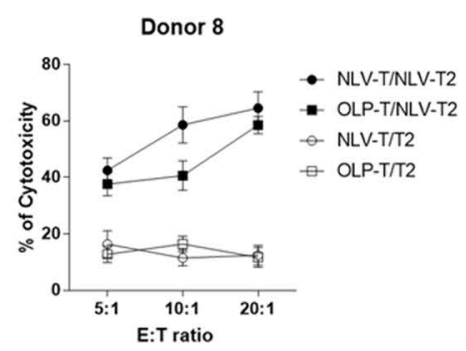

(d)
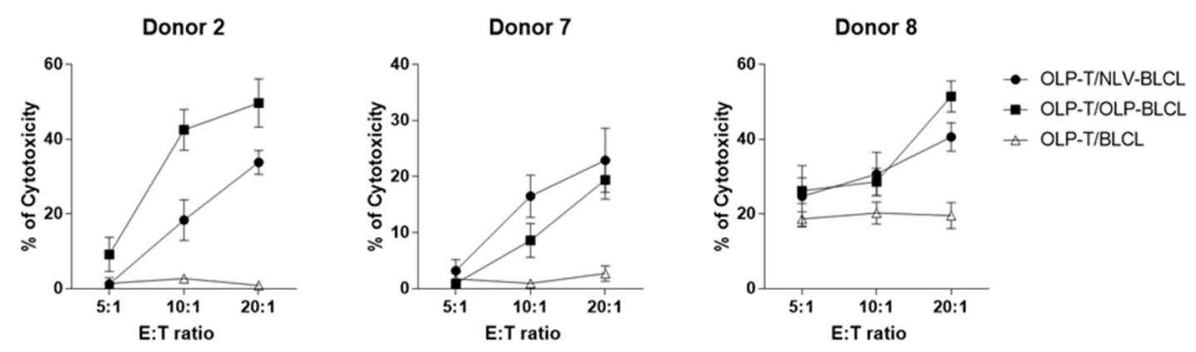

(e)

Donor 9

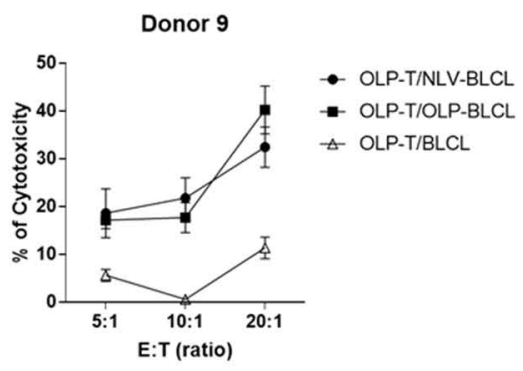

Fig. 2

Cytotoxicity of the HCMV pp65-specific CD8+ T-cells generated with OLP or the NLV peptide

(a) Frequency of NLV-specific CD8 ${ }^{+} \mathrm{T}$ cells generated from PBMCs from Donors 2,7, and 8 by stimulation with the immunodominant NLV peptide or OLP. The cultured cells were analyzed at day 14 by flow cytometry using an anti-CD8 antibody and the HCMV pp65 pentamer. (b) The frequency of IFN- $\gamma^{+} \mathrm{CD} 8{ }^{+}$cells was determined by flow cytometry. Data from a representative experiment are shown. (c) Cytotoxic activity against NLV-T2 cells. (d) The cytotoxic activity of OLP-T against either NLV-BLCL or OLP-BLCL. (e) Cytotoxic activity of CTLs generated from the PBMCs of an HLA-A*24:02-expressing donor using the NLV peptide or OLP. The cytotoxic activity of the CTLs against NLV-BLCL or OLP-BLCL was measured. Results are expressed as the mean \pm SEM. ${ }^{*} P<0.05$. 
(a)

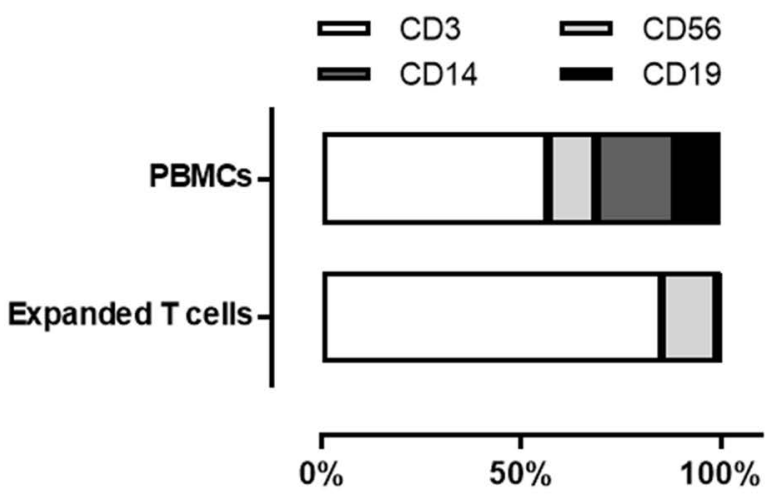

(b)

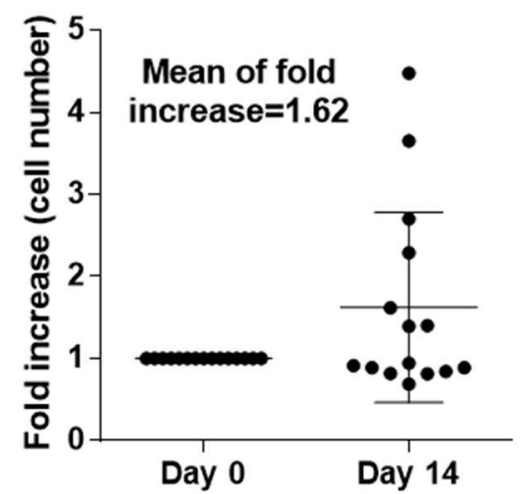

(c)

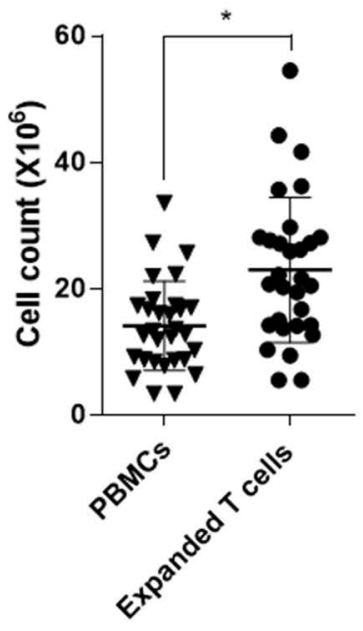

Fig. 3

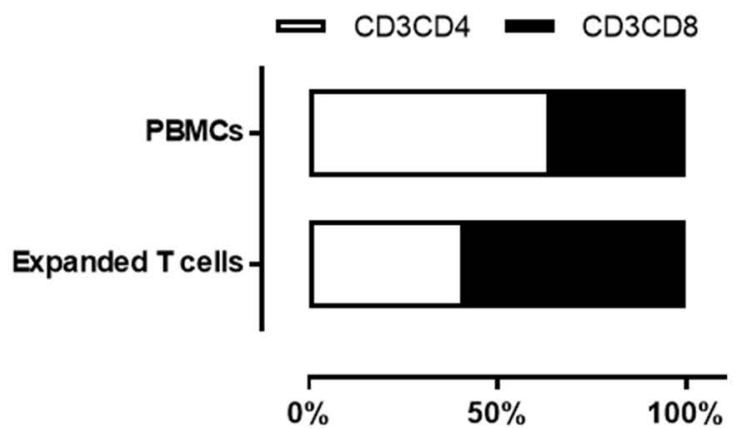

(d)

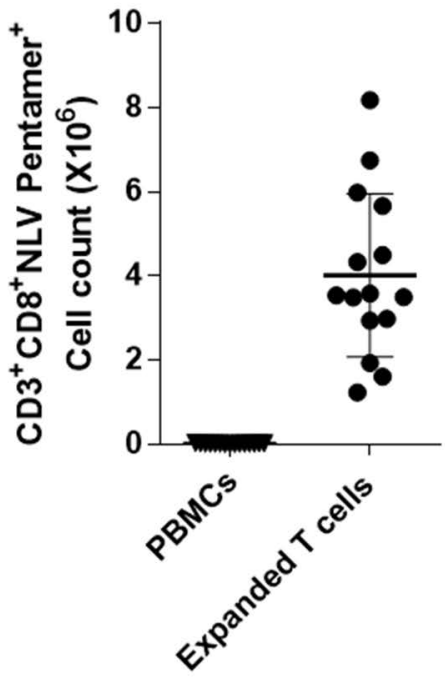

Phenotypic analysis of the T cells

(a) Phenotypic analysis of freshly isolated PBMCs and the expanded T cells after 14 days of culture with OLP. The percentages of cells expressing CD3, CD4, CD8, CD56 (NK cells), CD14 (monocytes), and CD19 (B cells) was assessed by flow cytometry. ${ }^{*} \mathrm{P}<0.05$. (b) The relative increase in $\mathrm{CD}^{+} \mathrm{T}$ cells generated using the OLP (day 14) compared with the numbers in freshly isolated PBMCs (day 0). Data from five independent experiments with each of the three donors are shown. (c) Absolute numbers of PBMCs and expanded T cells 14 days after expansion with OLP. (d) Analysis of CD3 ${ }^{+} \mathrm{CD} 8{ }^{+} \mathrm{NLV}$ pentamer ${ }^{+}$cells before and after culture with OLP for 14 days. Data from five independent experiments with each of the three donors are shown. ${ }^{*} P<0.05$, ${ }^{* * *} P<0.001$.

cytotoxic activity against autologous NLV-BLCL and OLPBLCL, but NLV-T did not (Fig. 2e). These results suggest that the OLP induced functional HCMV-specific CTLs from healthy donors bearing HLA-A*02:01 or HLA-A*24:02.

\section{Phenotype of HCMV pp65-specific CTLs}

The PBMCs and the corresponding expanded $\mathrm{T}$ cells generated using OLP were assessed for cell surface phenotype by flow cytometry. Compared with freshly isolated PBMCs, there was a marked increase in the frequency of $\mathrm{CD}^{+} \mathrm{CD} 8^{+} \mathrm{T}$ cells after 14 days of culture with OLP. In particular, there was a sharp increase in the frequency of $\mathrm{CD}^{+}{ }^{+} \mathrm{CD} 8^{+} \mathrm{T}$ cells (from $21.5 \%$ to $53.5 \%$ ). By contrast, the frequencies of $\mathrm{CD} 3^{+} \mathrm{CD}^{+} \mathrm{T}$ cells and $\mathrm{CD} 56^{+} \mathrm{NK}$ cells did not change significantly, and the $\mathrm{CD} 14^{+}$monocytes and CD19+ $\mathrm{B}$ cells almost disappeared $(0.5 \%$ and $0.8 \%$ at day 14 , respectively) (Fig. 3a). Therefore, only $\mathrm{CD}^{+}{ }^{+} \mathrm{CD} 8^{+} \mathrm{T}$ cells expanded in response to OLP. In addition, there was an increase in the frequency of activated $\mathrm{CD}^{+} \mathrm{T}$ cells, as indicated by staining for CD69 (data not shown). When the PBMCs were cultured with OLP for 14 days, the number 
of total cells increased on average by only 1.62-fold (Fig. 3B). Nevertheless, the numbers of $\mathrm{CD}^{+} \mathrm{T}$ cells increased by 3.8-fold on average (data not shown). Even more strikingly, the numbers of HCMV pp65 pentamer ${ }^{+}$cells rose by an average of 127.6-fold (data not shown). On average, therefore, $20 \mathrm{ml}$ blood yielded $1.4 \times 10^{7} \mathrm{PBMCs}$, and the protocol shown in Fig. $1 \mathrm{~b}$ generated $2.3 \times 10^{7} \mathrm{CD}^{+} \mathrm{T}$ cells (Fig. 3c). In addition, the OLP stimulation induced a 308fold increase in the numbers of NLV pentamer ${ }^{+} \mathrm{CD}^{+} \mathrm{T}$ cells after 14 days compared with the numbers in freshly isolated PBMCs (Fig. 3d). These results suggest that OLP induces NLV-specific CTLs but not NLV-specific CD4 $4^{+} \mathrm{T}$ cells.

\section{Discussion}

CMV disease continues to result in high mortality in recipients of $\mathrm{T}$ cell-depleted grafts subjected to prolonged immunosuppression. In particular, GvHD and delayed immune reconstitution after HSCT or solid organ transplants are associated with a significant risk of post-transplant infection or reactivation (Chan and Logan, 2017).

Several clinical trials have assessed the efficacy of adoptive immunotherapy with antigen-specific $T$ cells in preventing HCMV disease after transplantation (Bao et al., 2012). However, this treatment relies on standard ex vivo culture methods, whereby not only HCMV-specific CTLs, but also BLCLs or dendritic cells must be produced. This restriction has significantly hampered research into the effectiveness of this therapy in various patient groups (Ramadan, 2008). Therefore, a more rapid and effective method for generating HCMV-specific CTL is required.

We first performed experiments with PBMCs isolated from nine healthy donors, but only three donors were used for further experiments. Because the frequency of HCMV-specific T cells in healthy volunteers is very low and highly variable, the PBMCs were screened for NLV epitope-specific CTLs to verify the induction and proliferation of CTLs, and a frequency of at least $0.2 \% \mathrm{NLV}$ epitope-specific $C D 8^{+} \mathrm{T}$ cells was used as a cut-off.

In this study, we established a culture method for producing HCMV-specific CTLs. In this process, PBMCs are stimulated for 14 days in the presence of IL-2 with OLP that span the HCMV pp65 protein. This method is independent of the separate production of APCs and eliminates the need for a viral expression system. As a result, it is simple, fast, and economical. Furthermore, the use of OLP as the antigen exposes the PBMCs to a variety of epitopes, which reduces the problem posed by HLA restriction. This method increased the number of HCMV pp65 pentamer ${ }^{+}$cells by more than 100 -fold. Moreover, the peptide-expanded T lymphocytes exerted cytolytic activity. HCMV-specific T cells generated by OLP stimulation (OLP-T) killed an HLA-A*02:01-expressing cell line (T2 cells) loaded with NLV peptide (NLV-T2), as well as autologous BLCLs loaded with either the NLV peptide (NLV-BLCL) or OLP (OLP-BLCL). The cytolytic activity was specific for peptide- or OLP-loaded target cells, even at the highest the E:T ratio. In addition, we demonstrated the cytolytic activity of CTLs generated from an HLA-A*24:02expressing donor. OLP-T generated from an HLA-A*24:02 donor killed NLV-BLCL and OLP-BLCL, but HCMV-specific $T$ cells generated by NLV peptide stimulation (NLV-T) did not kill either NLV-BLCL or OLP-BLCL. These data suggest that stimulation with OLP induces antigen-specific T lymphocytes without HLA restriction.

In addition, on average, this protocol generated $2.3 \times$ $10^{7} \mathrm{~T}$ cells from $20 \mathrm{ml}$ blood. In general, $1-10 \times 10^{7} \mathrm{~T}$ cells are transferred in adoptive therapy (Cobbold et al., 2005; Rauser et al., 2004; Robbins et al., 2015). Thus, using this protocol, it is possible to derive the number of cells needed for adoptive therapy. Therefore, this protocol is suitable for further research on the merits of adoptive immunotherapy after HSCT.

More research is needed to determine whether CTLs can be derived from HCMV antibody-negative donors. It is also necessary to determine whether specific CTLs can be generated against the other viruses that cause complications after transplantation, including herpes simplex virus, EBV, varicella zoster virus, and adenovirus. The protocol we describe here is likely to be useful for selectively inducing CTL that are specific for these viruses as well. It may also be useful for preparing tumor-specific $\mathrm{T}$ cells.

Acknowledgments. This research was supported by the Bio \& Medical Technology Development Program of the National Research Foundation, funded by the Korean government (grant No. NRF-2017M3A9C8062622).

\section{References}

Aandahl EM, Michaelsson J, Moretto WJ, Hecht FM, Nixon DF (2004): Human CD4+ CD25 + regulatory T cells control T-cell responses to human immunodeficiency virus and cytomegalovirus antigens. J. Virol. 78, 2454-2459. https://doi.org/10.1128/JVI.78.5.2454-2459.2004

Aiello AE, Simanek AM (2012): Cytomegalovirus and immunological aging: the real driver of HIV and heart disease? J. Infect. Dis. 205, 1772-1774. https://doi.org/10.1093/ infdis/jis288

Bao L, Cowan MJ, Dunham K, Horn B, Mcguirk J, Gilman A, Lucas KG (2012): Adoptive immunotherapy with CMV-specific cytotoxic $\mathrm{T}$ lymphocytes for stem cell transplant patients with refractory CMV infections. J. Immunother. 35, 293-298. https://doi.org/10.1097/ CJI.0b013e31824300a2 
Biron KK (2006): Antiviral drugs for cytomegalovirus diseases. Antiviral Res. 71, 154-163. https://doi.org/10.1016/j. antiviral.2006.05.002

Chan ST, Logan AC (2017): The clinical impact of cytomegalovirus infection following allogeneic hematopoietic cell transplantation: Why the quest for meaningful prophylaxis still matters. Blood Rev.31,173-183. https:// doi.org/10.1016/j.blre.2017.01.002

Chevillotte M, Landwehr S, Linta L, Frascaroli G, Lüske A, Buser C, Mertens T, Einem JV (2009): Major tegument protein pp65 of human cytomegalovirus is required for the incorporation of pUL69 and pUL97 into the virus particle and for viral growth in macrophages. J. Virol. 83, 2480-2490. https://doi.org/10.1128/JVI.01818-08

Chou SW (2001): Cytomegalovirus drug resistance and clinical implications. Transpl. Infect. Dis. 3 (Suppl. 2), 20-24. https://doi.org/10.1034/j.1399-3062.2001.00004.X

Cihlar T, Fuller MD, Mulato AS, Cherrington JM (1998): A point mutation in the human cytomegalovirus DNA polymerase gene selected in vitro by cidofovir confers a slow replication phenotype in cell culture. Virology 248, 382-393. https://doi.org/10.1006/viro.1998.9299

Cobbold M, Khan N, Pourgheysari B, Tauro S, McDonald D, Osman H, Assenmacher M, Billingham L, Steward C, Crawley C, Olavarria E, Goldman J, Chakraverty R, Mahendra P, Craddock C, Moss PA (2005): Adoptive transfer of cytomegalovirus-specific CTL to stem cell transplant patients after selection by HLA-peptide tetramers. J. Exp. Med. 202, 379-386. https://doi. org/10.1084/jem.20040613

Gallez-Hawkins GM, Thao L, Palmer J, Dagis A, Li X, Franck AE, Tegtmeier B, Lacey SF, Diamond DJ, Forman SJ, Zaia JA (2009): Increased programmed death-1 molecule expression in cytomegalovirus disease and acute graftversus-host disease after allogeneic hematopoietic cell transplantation. Biol. Blood. Marrow. Transplant. 15, 872-880. https://doi.org/10.1016/j.bbmt.2009.03.022

Gerna G, Baldanti F, Sarasini A, Furione M, Percivalle E, Revello MG, Zipeto D, Zella D (1994): Effect of foscarnet induction treatment on quantitation of human cytomegalovirus (HCMV) DNA in peripheral blood polymorphonuclear leukocytes and aqueous humor of AIDS patients with HCMV retinitis. The Italian Foscarnet Study Group. Antimicrob. Agents. Chemother. 38, 38-44. https://doi.org/10.1128/AAC.38.1.38

Hasanzamani B, Hami M, Zolfaghari V, Torkamani M, Ghorban Sabagh M, Ahmadi Simab S (2016): The effect of cytomegalovirus infection on acute rejection in kidney transplanted patients. J. Renal. Inj. Prev. 5, 85-88. https://doi.org/10.15171/jrip.2016.18

Holden T, Smita A, Maria A, Xiao-Song H, Louis J, Vernon C (2001): Factors affecting the efficiency of CD8+ T cell cross-priming with exogenous antigens. J. Immunol. 166, 7268-7275. https://doi.org/10.4049/jimmunol.166.12.7268

Koc Y, Miller KB, Schenkein DP, Griffith J, Akhtar M, DesJardin J, Snydman DR (2000): Varicella zoster virus infections following allogeneic bone marrow transplanta- tion: frequency, risk factors, and clinical outcome. Biol. Blood. Marrow. Transplant. 6, 44-49. https://doi. org/10.1016/S1083-8791(00)70051-6

Leen AM, Myers GD, Sili U, Huls MH, Weiss H, Leung KS, Carrum G, Krance RA, Chang CC, Molldrem JJ, Gee AP, Brenner MK, Heslop HE, Rooney CM, Bollard CM (2006): Monoculture-derived $\mathrm{T}$ lymphocytes specific for multiple viruses expand and produce clinically relevant effects in immunocompromised individuals. Nature Med.12, 1160-1166. https://doi.org/10.1038/nm1475

Leen AM, Tripic T, Rooney CM (2010): Challenges of T cell therapies for virus-associated diseases after hematopoietic stem cell transplantation. Expert Opin. Biol. Ther. 10, 337-351. https://doi.org/10.1517/14712590903456003

Li CR, Greenberg PD, Gilbert MJ, Goodrich JM, Riddell SR (1994): Recovery of HLA-restricted cytomegalovirus (CMV)specific T-cell responses after allogeneic bone marrow transplant: correlation with CMV disease and effect of ganciclovir prophylaxis. Blood 83, 1971-1979. https:// doi.org/10.1182/blood.V83.7.1971.1971

Lilleri D, Gerna G, Zelini P, Chiesa A, Rognoni V, Mastronuzzi A, Giorgiani G, Zecca M, Locatelli F (2012): Monitoring of human cytomegalovirus and virus-specific T-cell response in young patients receiving allogeneic hematopoietic stem cell transplantation. PLoS One 7, e41648. https://doi.org/10.1371/journal.pone.0041648

McLaughlin-Taylor E, Pande H, Forman SJ, Tanamachi B, Li CR, Zaia JA, Greenberg PD, Riddell SR (1994): Identification of the major late human cytomegalovirus matrix protein pp65 as a target antigen for CD8+ virus-specific cytotoxic T lymphocytes. J. Med. Virol. 43, 103-110. https://doi.org/10.1002/jmv.1890430119

Peggs K, Verfuerth S, Mackinnon S (2001): Induction of cytomegalovirus (CMV)-specific T-cell responses using dendritic cells pulsed with CMV antigen: a novel culture system free of live CMV virions. Blood 97, 994-1000. https://doi.org/10.1182/blood.V97.4.994

Potena L, Solidoro P, Patrucco F, Borgese L (2016): Treatment and prevention of cytomegalovirus infection in heart and lung transplantation: an update. Expert Opin. Pharmacother. 17, 1611-1622. https://doi.org/10.1080/1 4656566.2016.1199684

Ramadan G (2008): Epstein-Barr virus-transformed B-cells as efficient antigen presenting cells to propagate Aspergillus-specific cytotoxic T-lymphocytes. Egypt. J. Immunol. 15, 145-157.

Rauser G, Einsele H, Sinzger C, Wernet D, Kuntz G, Assenmacher M, Campbell JD, Topp MS (2004): Rapid generation of combined CMV-specific CD4+ and CD8+ T-cell lines for adoptive transfer into recipients of allogeneic stem cell transplants. Blood 103, 3565-3572. https:// doi.org/10.1182/blood-2003-09-3056

Reddehase MJ, Mutter W, Munch K, Buhring HJ, Koszinowski UH (1987): CD8-positive T lymphocytes specific for murine cytomegalovirus immediate-early antigens mediate protective immunity. J. Virol. 61, 3102-3108. https://doi.org/10.1128/JVI.61.10.3102-3108.1987 
Robbins PF, Kassim SH, Tran TL, Crystal JS, Morgan RA, Feldman SA, Yang JC, Dudley ME, Wunderlich JR, Sherry RM, Kammula US, Hughes MS, Restifo NP, Raffeld M, Lee CC, Li YF, El-Gamil M, Rosenberg SA (2015): A pilot trial using lymphocytes genetically engineered with an NY-ESO-1-reactive T-cell receptor: long-term follow-up and correlates with response. Clin. Cancer Res. 21, 1019-1027. https://doi.org/10.1158/1078-0432. CCR-14-2708

Sahin U, Toprak SK, Atilla PA, Atilla E, Demirer T (2016): An overview of infectious complications after allogeneic hematopoietic stem cell transplantation. J. Infect. Chemother. 22, 505-514. https://doi.org/10.1016/j. jiac.2016.05.006

Sylwester AW, Mitchell BL, Edgar JB, Taormina C, Pelte C, Ruchti F, Sleath PR, Grabstein KH, Hosken NA, Kern F, Nelson JA, Picker LJ (2005): Broadly targeted human cytomegalovirus-specific CD4+ and CD8+ T cells dominate the memory compartments of exposed subjects.
J. Exp. Med. 202, 673-685. https://doi.org/10.1084/ jem.20050882

Tomtishen III (2012): Human cytomegalovirus tegument proteins (pp65, pp71, pp150, pp28).Virol J. 9,22-29. https:// doi.org/10.1186/1743-422X-9-22

Vannucchi AM, Glinz S, Bosi A, Caporale R, Rossi-Ferrini P (2001): Selective ex vivo expansion of cytomegalovirus-specific $\mathrm{CD} 4+$ and $\mathrm{CD} 8+\mathrm{T}$ lymphocytes using dendritic cells pulsed with a human leucocyte antigen $A^{*} 0201-$ restricted peptide. Br.J.Haematol.113, 479-482. https:// doi.org/10.1046/j.1365-2141.2001.02777.x

Varani S, Frascaroli G, Landini MP, Soderberg-Naucler C (2009): Human cytomegalovirus targets different subsets of antigen-presenting cells with pathological consequences for host immunity: implications for immunosuppression, chronic inflammation and autoimmunity. Rev. Med. Virol.19,131-145. https://doi. org/10.1002/rmv.609 